\title{
Stabilization of Activity of Oxidoreductases by Their Immobilization onto Special Functionalized Glass and Novel Aminocellulose Film Using Different Coupling Reagents
}

\author{
Joerg C. Tiller, ${ }^{\dagger,}, \S$ Raino Rieseler, ${ }^{\dagger}$ Peter Berlin, ${ }^{*}{ }^{\dagger}$ and Dieter Klemm ${ }^{\ddagger}$ \\ Forschungszentrum Jülich GmbH, ZEL, D-52425 Jülich, Germany, and Institut für Organische und \\ Makromolekulare Chemie, Friedrich-Schiller-Universität, Humboldtstrasse 10, D-07743 Jena, Germany
}

Received April 2, 2002

\begin{abstract}
Glucose oxidase (GOD), horseradish peroxidase (HRP), and lactate oxidase (LOD) were covalently immobilized on special $\mathrm{NH}_{2}$-functionalized glass and on a novel $\mathrm{NH}_{2}$-cellulose film via 13 different coupling reagents. The properties of these immobilized enzymes, such as activity, storage stability, and thermostability, are strongly dependent on the coupling reagent. For example, GOD immobilized by cyanuric chloride on the $\mathrm{NH}_{2}$-cellulose film loses approximately half of its immobilized activity after 30 days of storage at $4{ }^{\circ} \mathrm{C}$ or after treatment at $65{ }^{\circ} \mathrm{C}$ for $30 \mathrm{~min}$. In contrast, GOD immobilized by L-ascorbic acid onto the same $\mathrm{NH}_{2}$-cellulose film retains $90 \%$ of its initial activity after 1 year of storage at $4{ }^{\circ} \mathrm{C}$ and $92 \%$ after heat treatment at $65{ }^{\circ} \mathrm{C}$ for $30 \mathrm{~min}$. Unlike GOD, in the case of LOD only immobilization on special $\mathrm{NH}_{2}-$ functionalized glass, e.g., via cyanuric chloride, led to a stabilization of the enzyme activity in comparison to the native enzyme. The operational stability of immobilized HRP was up to 40 times higher than that of the native enzyme if coupling to the new $\mathrm{NH}_{2}$-cellulose film led to an amide or sulfonamide bond. Regarding the kinetics of the immobilized enzymes, the coupling reagent plays a minor role for the enzyme substrate affinity, which is characterized by the apparent Michaelis constant $\left(K_{\mathrm{M}, \mathrm{app}}\right)$. The $\mathrm{NH}_{2}$-functionalized support material as well as the immobilized density of the protein and/or immobilized activity has a strong influence on the $K_{\mathrm{M} \text {,app }}$ value. In all cases, $K_{\mathrm{M} \text {,app }}$ decreases with increasing immobilized enzyme protein density and particularly drastically for GOD.
\end{abstract}

\section{Introduction}

Biomolecule-functionalized support surfaces are of fundamental importance for analyte recognition in biosensor technology or as biocatalysts in biotechnology. To develop enzyme-functionalized support surfaces for biosensors, numerous support materials have been applied with varying degrees of success. The limited functional stability of enzyme-functionalized supports still restricts their practical application, e.g., for biosensors in medical in vivo diagnostics.

Oxidoreductase enzymes, e.g., glucose oxidase (GOD) and lactate oxidase (LOD), are still of great importance as analyte recognition systems in biosensors. Various immobilization approaches, such as ionic and covalent immobilization, crosslinking, the bioaffinity-based method, graft copolymerization, and entrapment, have been described. ${ }^{1-7}$ However, in most cases, the immobilization techniques could not fulfill all requirements for targeted application, like high enzyme stability and reactivity under the given process conditions. Of the immobilization methods, covalent binding often exhibits the highest stabilization of enzyme activities because

* To whom correspondence should be addressed. E-mail: P.Berlin@ fz-juelich.de.

Forschungszentrum Jülich GmbH.

$\doteqdot$ Friedrich-Schiller-Universität.

\$ Present address: Freiburger Materialforschungszentrum, Albert-Ludwigs-Universität, Stefan-Meier-Str. 21, 79104 Freiburg i. Br., Germany. the active conformation of the immobilized enzyme is stabilized. ${ }^{8}$ The support material and the coupling reagent thus provide the microenvironment, including the hydrophilic-lipophilic balance, $\mathrm{pH}$ value, and ionic strength. The coupling reagent additionally controls the protein bonding (how many and which amino acid residues are chemically changed). Both factors strongly influence the activity and the kinetic properties of the immobilized enzymes.

Surprisingly, despite the long history of enzyme immobilization, there are, especially in the case of oxidoreductase enzymes, only a few examples of systematic investigations of the influence of coupling reagents on the properties of the immobilized enzymes, ${ }^{9,10}$ while most studies investigate the influence of the support. ${ }^{11,12}$

The goal of our recent investigations is the development of new ultrathin and transparent solid phases with an incorporated oxidoreductase enzyme for fiberoptical biosensors. To this end, a novel film-forming $\mathrm{NH}_{2}$-cellulose derivative, 6-deoxy-6-(4-aminophenyl)-amino)cellulosetosylate $\left(\mathrm{NH}_{2}\right.$-cellulose film), ${ }^{13}$ and a novel $\mathrm{NH}_{2}$-functionalized coating on glass $\left(\mathrm{NH}_{2} \text {-glass }\right)^{14}$ were developed as transparent $\mathrm{NH}_{2}$-functional support matrixes. In this study, we present the 13 in part new $\mathrm{NH}_{2}$-reactive coupling reagents for the immobilization of the oxidoreductase enzymes glucose oxidase, horseradish peroxidase, and lactate oxidase on the $\mathrm{NH}_{2}$-functionalized supports. It is shown that the immobilization method can have a strong influence on the 
activity of the immobilized enzymes, their storage stability, thermostability, and their operational stability. The kinetic properties of the immobilized enzymes were also investigated.

\section{Experimental Section}

Materials. Glucose oxidase (GOD) EC 1.1.3.4 from Aspergillus niger Grade II (60 U/mg), horseradish peroxidase (HRP) EC 1.11.1.7 Grade II (200 U/mg), and lactate oxidase (LOD) from Pediococcus species (20 U/mg) were purchased from Sigma, and azinobis-3-ethylbenzothiazoline-6-sulfonic acid (ABTS) was purchased from Boehringer (Mannheim, Germany). All other chemicals (analytical grade or purer) were from Aldrich or Fluka and were used without further purification.

Preparation of the $\mathbf{N H}_{2}$-Glass Surfaces. The $\mathrm{NH}_{2}$-glass surfaces were prepared on the tips of glass rods (diameter 1 $\mathrm{mm}$, length $10 \mathrm{~cm}$ ). These rods were coated with an ultrathin $\mathrm{SiO}_{2}$ layer (some hundred nanometers in thickness). A commercial procedure - the so-called Pyrosil technique (Sura Chemicals GmbH, Jena, Germany)-is especially well suited for this purpose. Within $1-2 \mathrm{~h}$ in air, due to the influence of the atmospheric humidity, the $\mathrm{SiO}_{2}$ coating forms silanols which are condensed to a vitreous polymer film ("polymerized $\mathrm{SiO}_{2}$ ").

This polymerized $\mathrm{SiO}_{2}$ was then treated with (3-aminopropyl)triethoxysilane in toluene. The procedure is described elsewhere in more detail (see ref 14).

Preparation of the $\mathbf{N H}_{2}$-Cellulose Surfaces. A glass rod (as used above) was dipped into a $5 \%$ solution of 6-deoxy6-(4-aminophenyl)amino cellulose tosylate $\left(\mathrm{NH}_{2}\right.$-cellulose) in $N, N$-dimethylacetamide (DMA). The $\mathrm{NH}_{2}$-cellulose synthesis is described elsewhere. ${ }^{13}$ The transparent film formed at room temperature was air-dried for at least $2 \mathrm{~h}$.

Enzyme Immobilization Procedures. (i) Glutaraldehyde Activation. The $\mathrm{NH}_{2}$-cellulose film on the glass rod was swollen in DMA for about $10 \mathrm{~s}$ and then immersed in $20 \%$ aqueous glutaraldehyde solution and incubated at room temperature for $10 \mathrm{~min}$. The $\mathrm{NH}_{2}$-glass rod was immersed in the same solution for $15 \mathrm{~min}$. The activated support surfaces were then washed with bidistilled water and placed in an enzyme solution in bidistilled water.

(ii) Ascorbic Acid Activation. The $\mathrm{NH}_{2}$-functionalized supports were placed in a saturated solution of ascorbic acid in DMA (400 mg/mL) and incubated at room temperature for $15 \mathrm{~min}$. The samples were then thoroughly rinsed with bidistilled water and immediately added to an enzyme solution in bidistilled water.

(iii) Benzoquinone Activation. The $\mathrm{NH}_{2}$ supports were placed in a DMSO/benzoquinone solution $(200 \mathrm{mg} / \mathrm{mL})$. After incubation for $15 \mathrm{~min}$ at room temperature, the samples were rinsed until the rinsing solution was no longer yellowish and then added to an enzyme solution in bidistilled water.

(iv) Activation by Means of Aromatic Diacid Dichlorides, Aromatic Disulfonic Acid Dichlorides, and Cyanuric Chloride. The $\mathrm{NH}_{2}$-functionalized supports were added to a solution of $100 \mathrm{mg}$ of iso- and terephthaloyl chloride, 1,3-benzenedisulfonyl chloride, 4,4'-biphenyldis- ulfonyl chloride, or cyanuric chloride dissolved in $10 \mathrm{~mL}$ of DMA and incubated at room temperature for $15 \mathrm{~min}$. In the case of $\mathrm{NH}_{2}$-glass activation with cyanuric chloride, the incubation time was $5 \mathrm{~min}$. The activated surfaces were then thoroughly rinsed with ethanol until they became clear, quickly washed with $100 \mathrm{mM}$ phosphate buffer, $\mathrm{pH}$ 7.0, and immediately placed into an enzyme solution in the same buffer, which had previously been cooled to $4{ }^{\circ} \mathrm{C}$.

(v) Activation by Means of Aromatic Dialdehydes and Diketones. The $\mathrm{NH}_{2}$-functionalized supports were placed into a solution of $100 \mathrm{mg}$ of iso- and terephthalaldehyde, 1,3- or 1,4-diacetylbenzene dissolved in DMA, incubated at room temperature for $15 \mathrm{~min}$, rinsed with ethanol and bidistilled water, and added to an enzyme solution in bidistilled water.

(vi) Diazo Coupling. A $\mathrm{NH}_{2}$-cellulose film was swollen in DMA for $10 \mathrm{~s}$ and then placed into $10 \mathrm{~mL}$ of ice-cooled $0.5 \mathrm{M} \mathrm{HCl}$. One milliliter of a $1 \mathrm{M}$ solution of $\mathrm{NaNO}_{2}$ in bidistilled water was added dropwise turning the polymer film yellow. After incubation for another $10 \mathrm{~min}$ the film was rinsed with ice-cooled water and placed into an enzyme solution in $100 \mathrm{mM}$ phosphate buffer, $\mathrm{pH}$ 7.0.

Enzyme Immobilization. An activated $\mathrm{NH}_{2}$-functionalized support was immersed in $0.1 \mathrm{~mL}$ of an enzyme solution: $1 \mathrm{mg}$ of enzyme per $\mathrm{mL}$ of bidistilled water (activation procedures i, ii, iii, and v) or $100 \mathrm{mM}$ phosphate buffer, pH 7.0 (activation procedures iv and vi), in an Eppendorf tube. After incubation at $4{ }^{\circ} \mathrm{C}$ for $16 \mathrm{~h}$ the nonattached enzyme was removed by rinsing with a stream of bidistilled water for at least $1 \mathrm{~min}$ and the sample was stored at $4{ }^{\circ} \mathrm{C}$ in bidistilled water.

Determination of Enzyme Loading and of the Michaelis Constant. (i) Immobilized Enzyme Activity. The immobilized enzyme activity was determined photometrically using a UV-vis spectrophotometer (Beckman DU-64). The enzyme-functionalized glass rod was placed in a cuvette containing a solution of the respective enzyme activity test system. In the cases of GOD and LOD a test system modified after Trinder and Webster was used ${ }^{15}$ containing 4-aminoantipyrine, 2,4,6-tribromo-3-hydroxybenzoic acid, and enzyme substrate dissolved in $100 \mathrm{mM}$ phosphate buffer, $\mathrm{pH}$ $7.0\left(\lambda_{\max }=514 \mathrm{~nm}, \epsilon=27.2 \mathrm{~cm}^{2} / \mu \mathrm{mol}\right)$. The determination of the immobilized HRP was carried out according to the ABTS method (1 mg of ABTS per $\mathrm{mL}$ of $100 \mathrm{mM}$ acetate buffer, pH 5.0, $10 \mathrm{mM} \mathrm{H}_{2} \mathrm{O}_{2}$ ) described by Gallati ${ }^{16}\left(\lambda_{\max }=\right.$ $\left.414 \mathrm{~nm}, \epsilon=36.8 \mathrm{~cm}^{2} / \mu \mathrm{mol}\right)$. While the glass rod was stirred in the solution, the increase of absorbance was measured at $\lambda_{\text {max }}$ of the test system used.

The above-mentioned test systems and procedures were used to determine the $K_{\mathrm{M} \text {,app }}$ values of the immobilized enzymes by measuring the initial rate of substrate conversion in the concentration ranges of $1-200 \mathrm{mM}$ glucose (GOD), 0.01-10 $\mathrm{mM} \mathrm{H} \mathrm{H}_{2} \mathrm{O}_{2}$ (HRP), and 0.05-10 mM L-lactate (LOD). The $K_{\mathrm{M} \text {,app }}$ values were calculated by mathematical hyperbola curve fitting (standard error range $2-13 \%$ ) of the well-known Michaelis-Menten algorithm $\left(v=v_{\max } S /\left(K_{\mathrm{M}}\right.\right.$ $+S)$ ) by means of Sigma Plot 5.0 scientific graphic software (Jandel Scientific).

(ii) Operational Stability. The activity of an HRPfunctionalized support surface was determined by continu- 

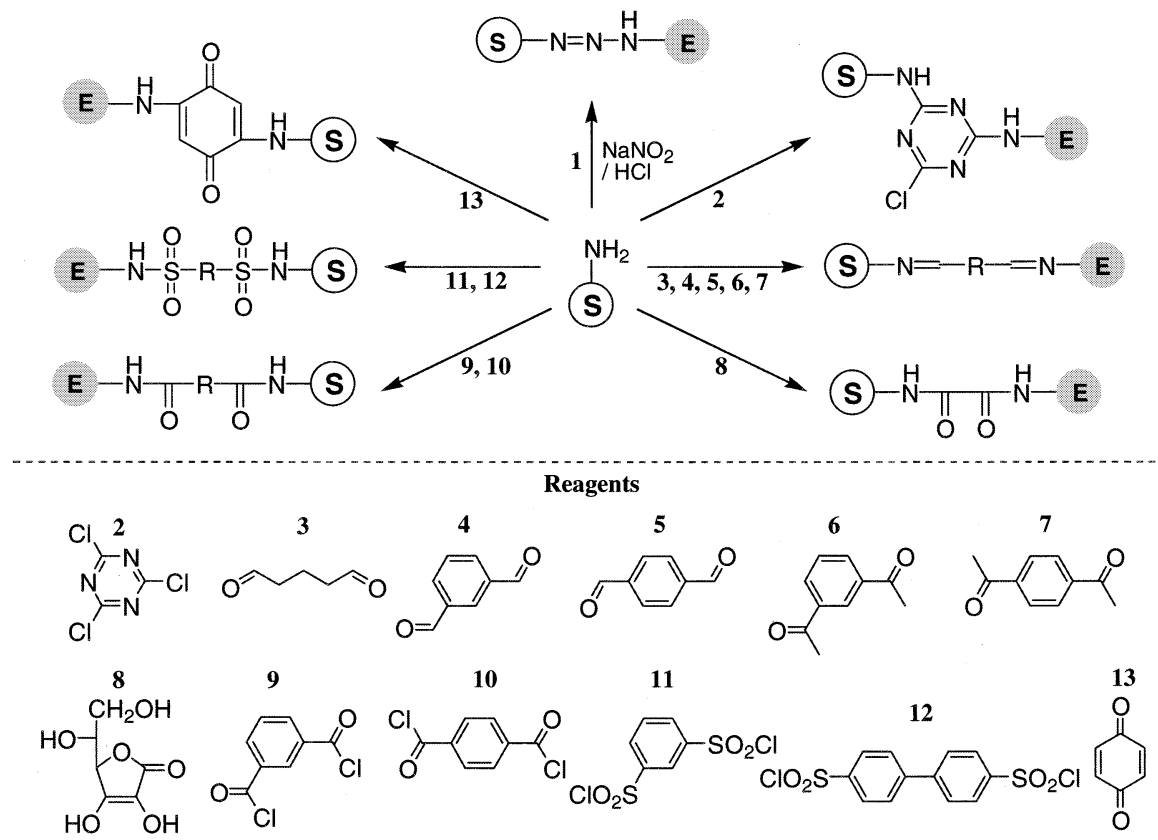

Figure 1. Structural formulas: coupling reagents and coupling structures between $\mathrm{NH}_{2}$ support $(\mathrm{S})$ and enzyme protein (E).

ously measuring the enzyme activity using the test system described above for 30-40 min with a hydrogen peroxide concentration of $10 \mathrm{mM}$. The half-life of the enzyme was calculated following a procedure suggested by Adediran and Lambeir whereby the half-life time $\left(\tau_{1 / 2}\right)$ was calculated by $\tau_{1 / 2}=\ln (0.5) / \mathrm{k} .{ }^{17}$ The pseudo-first-order rate constant $\mathrm{k}$ was determined by mathematical exponential curve fitting of the first-order kinetic of HRP activity decrease $\left(v=v_{0} \mathrm{e}^{-(k t)}\right)$ by means of Sigma Plot 5.0.

(iii) Protein Determination. An activated $\mathrm{NH}_{2}$-functionalized support surface was treated with $1 \mu \mathrm{L}$ of a $\mathrm{GOD}$ solution in water $(1 \mathrm{mg} / \mathrm{mL})$ and incubated under humidified conditions at $4{ }^{\circ} \mathrm{C}$ for $1-16 \mathrm{~h}$. The nonattached enzyme protein was then washed off with $0.1 \mathrm{~mL}$ of bidistilled water. The protein content in the collected solution was determined by measuring the fluorescence of the FAD coenzyme group (excitation at $460 \mathrm{~nm}$, emission at $520 \mathrm{~nm}$ ) using a fluorescence spectrophotometer (Perkin-Elmer). Measurements with GOD solutions in the concentration range from 1 to $11 \mu \mathrm{g} / \mathrm{mL}$ gave a linear relation between emission intensity at $520 \mathrm{~nm}$ and GOD enzyme protein concentration. The immobilized activity was then calculated from the difference between the GOD concentration of the immobilization solution before and after immobilization.

\section{Results and Discussion}

The immobilization of the oxidoreductase enzymes glucose oxidase (GOD), lactate oxidase (LOD), and horseradish peroxidase (HRP) was performed on the tips of glass rods coated with the $\mathrm{NH}_{2}$-functionalized support. The rods allow easy handling of the attached reagent solid phases. To create the special $\mathrm{NH}_{2}$-glass, a glass rod was coated with a polymerized $\mathrm{SiO}_{2}$ layer and subsequently treated with (3aminopropyl)triethoxysilane (see ref 14). The cellulosic support was prepared by coating a glass rod with a novel $\mathrm{NH}_{2}$-cellulose film. The $\mathrm{NH}_{2}$-cellulose film is only some 200 $\mathrm{nm}$ in thickness as determined using atomic force microscopy and ellipsometry. ${ }^{18}$ The above-mentioned enzymes were covalently immobilized via 13 different coupling reagents, shown in Figure 1, onto both $\mathrm{NH}_{2}$-functionalized support surfaces using the various reaction possibilities of the $\mathrm{NH}_{2}$ groups. In all cases, the bifunctional reagents were used in great excess for activation of the matrix to avoid crosslinking, particularly, of the treated $\mathrm{NH}_{2}$-cellulose film. This is necessary because each reagent, if applied in low concentration, may lead to a different extent of cross-linking resulting in a different extent of swelling, which can affect the immobilization of enzymes.

As can be seen in Table 1, the amount of immobilized enzyme activity varies depending on the oxidoreductase enzyme, the nature of the support material, and the coupling reagent. GOD could be immobilized up to approximately $200 \mathrm{mU} / \mathrm{cm}^{2}$ on both $\mathrm{NH}_{2}$-cellulose and $\mathrm{NH}_{2}$-glass (see Table 1 ), which is close to the highest value of immobilized GOD activity described $\left(340 \mathrm{mU} / \mathrm{cm}^{2}\right) .{ }^{19} \mathrm{HRP}$ was immobilized up to $400 \mathrm{mU}$ via benzoquinone onto $\mathrm{NH}_{2}$-glass and up to $200 \mathrm{mU} / \mathrm{cm}^{2}$ onto $\mathrm{NH}_{2}$-cellulose films by means of various methods (see Table 1). The most suitable method for achieving high-immobilized LOD activity was coupling via 1,3-benzenedisulfonyl chloride and 4,4'-biphenyldisulfonyl chloride onto $\mathrm{NH}_{2}$-glass ( 330 and $339 \mathrm{mU} / \mathrm{cm}^{2}$ ). In the case of $\mathrm{NH}_{2}$-glass, there seems to be a relation between the molecule geometry of the bifunctional reacting aromatic coupling reagents and the immobilized GOD activity (cf. Table 1). Greatly varying values of immobilized enzyme activities were obtained by applying a series of 1,3- and 1,4bifunctional aromatic coupling reagents. The 1,3 coupling, for example, usually leads to a considerably lower enzyme immobilization efficiency than that obtained with the corresponding 1,4 coupling reactions. (Note that the aromatic 1,3 and 1,4 dialdehydes are an exception, where the values of the immobilized GOD enzyme activities hardly differ at all.) In contrast, this effect does not occur for $\mathrm{NH}_{2}$-cellulose 
Table 1. Activities of Oxidoreductase Enzymes GOD, HRP, and LOD Immobilized on $\mathrm{NH}_{2}$-Glass and $\mathrm{NH}_{2}$-Cellulose Films

\begin{tabular}{|c|c|c|c|c|c|c|c|}
\hline \multirow[b]{3}{*}{ no. } & \multirow[b]{3}{*}{ coupling $^{b}$} & \multicolumn{6}{|c|}{ immobilized enzyme activitiy ${ }^{a}\left(\mathrm{mU} / \mathrm{cm}^{2}\right)$} \\
\hline & & \multicolumn{2}{|c|}{ GOD } & \multicolumn{2}{|c|}{ HRP } & \multicolumn{2}{|c|}{ LOD } \\
\hline & & $\mathrm{NH}_{2}$-glass & $\mathrm{NH}_{2}$-cellulose & $\mathrm{NH}_{2}$-glass & $\mathrm{NH}_{2}$-cellulose & $\mathrm{NH}_{2}$-glass & $\mathrm{NH}_{2}$-cellulose \\
\hline 1 & $\mathrm{NaNO}_{2} / \mathrm{HCl}$ & $c$ & 194 & $c$ & 69 & $c$ & 220 \\
\hline 2 & cyanuric chloride & 168 & 78 & 24 & 59 & 265 & 119 \\
\hline 3 & glutaraldehyde & 160 & 187 & 70 & 206 & 175 & 100 \\
\hline 4 & isophthalaldehyde & 26 & 94 & 40 & 58 & 27 & 61 \\
\hline 5 & terephthalaldehyde & 24 & 56 & 23 & 48 & 32 & 21 \\
\hline 6 & 1,3-diacetylbenzene & 38 & 51 & 34 & 76 & 85 & 123 \\
\hline 7 & 1,4-diacetylbenzene & 57 & 70 & 14 & 104 & 88 & 52 \\
\hline 8 & L-ascorbic acid & 140 & 165 & 111 & 200 & 84 & 192 \\
\hline 9 & isophthaloyl chloride & 15 & 34 & 18 & 121 & 201 & 286 \\
\hline 10 & terephthaloyl chloride & 116 & 60 & 70 & 27 & 205 & 131 \\
\hline 11 & 1,3-benzenedisulfonyl chloride & 23 & 168 & 11 & 48 & 333 & $c$ \\
\hline 12 & 4,4'-biphenyldisulfoyl chloride & 82 & 27 & 12 & 35 & 339 & $c$ \\
\hline 13 & benzoquinone & 219 & 7 & 408 & 12 & 65 & 4 \\
\hline
\end{tabular}

${ }^{a}$ Samples used for stability and kinetics investigations were in a $10 \%$ range of the given values. ${ }^{b}$ For structural formulas of the coupling reagents see Figure 1. ${ }^{c}$ Not available.

films, possibly because it appears to be a multilayer consisting of unordered $\mathrm{NH}_{2}$-cellulose chains (about $100 \mathrm{~nm}$ size) in all space directions, which diminishes any spacer effects as observed earlier. ${ }^{20}$ An influence of the couplingmolecule geometry was not observed for the immobilized activity of HRP and LOD on either of the $\mathrm{NH}_{2}$-functionalized support surfaces.

A possible explanation for the lack of the geometry effect is that reactive amino acid residues, especially lysine (Lys) residues, are, in contrast to GOD, present at peripheral positions of the HRP and LOD enzyme molecules serving as binding sites for enzyme immobilization without deforming the active enzyme protein conformation.

Storage stability and thermostability are two important factors for the applicability of immobilized enzymes, because native enzymes usually quickly lose their activity. ${ }^{21}$ The greatest stabilizing effect for GOD activity regarding storage was achieved when the enzyme was immobilized via L-ascorbic acid and benzoquinone on $\mathrm{NH}_{2}$-glass where the enzyme showed $99 \%$ and $96 \%$, respectively, of its initial activity after 30 days at $4{ }^{\circ} \mathrm{C}$. The storage stability of immobilized GOD activity strongly depends on the coupling method. It does not significantly differ between the $\mathrm{NH}_{2}$ cellulose and the $\mathrm{NH}_{2}$-glass surface, except for the 1,3bifunctional aromatic coupling reagents (cf. Figure 2a). In the case of $\mathrm{NH}_{2}$-glass, GOD immobilized by means of 1,3bifunctional aromatic coupling reagents exhibits drastically lower storage stability than the enzyme immobilized by the respective 1,4-bifunctional aromatic reagents.

Apparently, there is a relation between the storage stability of the GOD-functionalized support surfaces and the low immobilized GOD activity or protein quantity in the 1,3coupling reaction (cf. Tables 1 and 2). Our conception is that, on one hand, the $\mathrm{NH}_{2}$-functionalized support structures and, on the other hand, the increasing immobilized enzyme activity or protein quantity will form the enzyme's own efficient microenvironment leading to enzyme activity stabilization (cf. below and ref 18).

The so-called geometry effect seems to be a spacer effect. It results from various spacer lengths in enzyme immobiliza- tion by means of 1,3- and 1,4-bifunctional aromatic coupling bonds since in the 1,3 coupling the spacer effect is in principle about $1 \AA$ shorter in comparison to the 1,4 coupling-as indicated by computer model estimates. The coupling with a 1,3-bifunctional aromatic reagent, which is sterically hindered compared to the respective 1,4-bifunctional aromatic reagent, results in a stronger deformation of the active enzyme conformation and/or a loss of (multipoint) bindings with the enzyme protein. The consequence is a higher conformational flexibility associated with a lower enzyme stability. This is also evident in the thermostability results (cf. below).

Wang et al. discuss a relation between the spacer effect and the immobilized enzyme concentration or activity of GOD immobilization on polyethylene membranes. ${ }^{22}$ On the basis of the their data, the authors conclude that there is considerable deformation of the GOD protein if the enzyme is immobilized on polyethylene membranes without an alkylene diamino spacer group.

The rate of inactivation of immobilized GOD decreases with greater storage time, e.g., GOD coupled via L-ascorbic acid to $\mathrm{NH}_{2}$-cellulose films loses $5 \%$ of its initial activity after 30 days, but retains $90 \%$ after storage for 12 months.

To investigate the thermostability, the GOD-functionalized films were treated in bidistilled water at $65{ }^{\circ} \mathrm{C}$ for $30 \mathrm{~min}$. Native GOD lost more than $70 \%$ of its initial activity under these conditions. GOD immobilized on both $\mathrm{NH}_{2}$-functionalized support materials exhibits lower thermal inactivation compared to the native enzyme. The cellulosic $\mathrm{NH}_{2}$-support stabilizes the enzyme to a greater extent than $\mathrm{NH}_{2}$-glass as seen in Figure $2 \mathrm{~b}$. The highest thermostability was achieved for GOD immobilized by means of L-ascorbic acid, diazo coupling, or glutaraldehyde onto $\mathrm{NH}_{2}$-cellulose film, where the enzyme retained $93 \%, 85 \%$, and $81 \%$, respectively, of the initial activity. After the heat treatment all other GODfunctionalized films lost more than $25 \%$ of their initial activity and, in the cases of GOD immobilized by means of isophthalaldehyde and 1,3-diacetylbenzene on $\mathrm{NH}_{2}$-glass, even as much as $100 \%$ (see Figure $2 \mathrm{~b}$ ). Similar to the results obtained for the storage stability, GOD coupled via 1,3- 
a

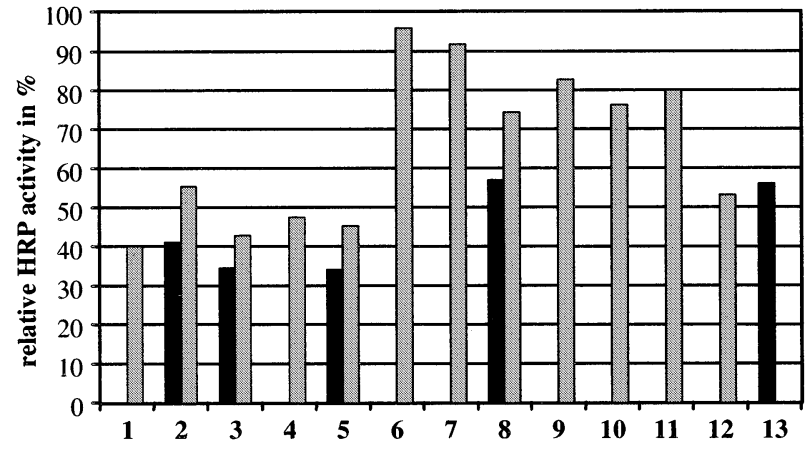

c

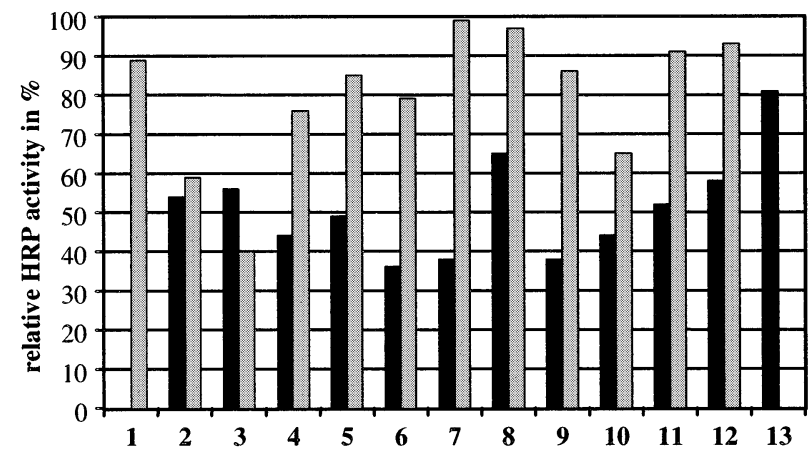

b

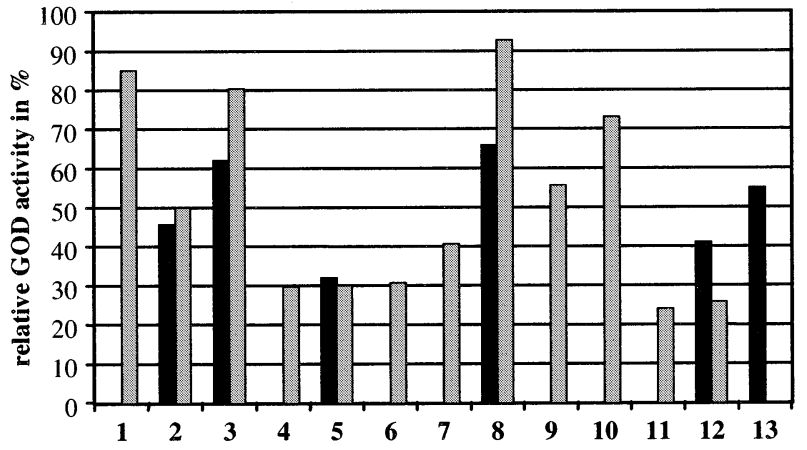

d

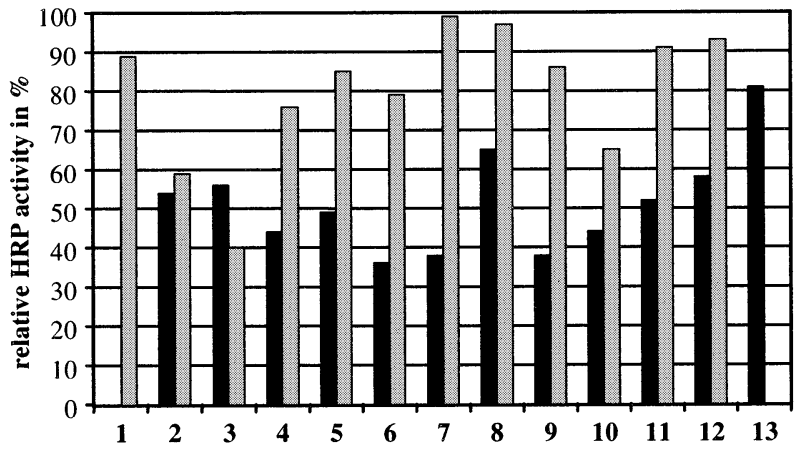

Figure 2. Storage stability and thermostability of GOD and HRP immobilized on $\mathrm{NH}_{2}$-glass (dark columns) and $\mathrm{NH}_{2}$-cellulose films (pale columns) using different coupling reagents (structural formulas see Figure 1): immobilized GOD (a) storage stability and (b) thermostability; immobilized HRP (c) storage stability and (d) thermostability. (To investigate the thermostability, the enzyme-functionalized support surfaces were treated in distilled water at $65{ }^{\circ} \mathrm{C}$ for $30 \mathrm{~min}$.)

Table 2. Operational Enzyme Stability of HRP Immobilized on $\mathrm{NH}_{2}$-Glass and $\mathrm{NH}_{2}$-Cellulose Films ${ }^{a}$

\begin{tabular}{|c|c|c|c|c|c|c|c|c|c|c|c|c|c|}
\hline \multirow[b]{2}{*}{$\mathrm{NH}_{2}$ support } & \multicolumn{13}{|c|}{ operational enzyme stability $\tau_{1 / 2}(\min )^{b, c}$} \\
\hline & 1 & 2 & 3 & 4 & 5 & 6 & 7 & 8 & 9 & 10 & 11 & 12 & 13 \\
\hline $\mathrm{NH}_{2}$-glass & $d$ & $d$ & 77 & 35 & $d$ & 42 & $d$ & 105 & 23 & 60 & $d$ & $d$ & 60 \\
\hline $\mathrm{NH}_{2}$-cellulose & 80 & 168 & 110 & 75 & 71 & 131 & 118 & 148 & 354 & 282 & 473 & 683 & $d$ \\
\hline
\end{tabular}

${ }^{a}$ Reaction conditions: $25^{\circ} \mathrm{C}, \mathrm{pH} \mathrm{5.0,10} \mathrm{mM} \mathrm{H}_{2} \mathrm{O}_{2}, 100 \mathrm{mM}$ ABTS. ${ }^{b}$ The half-life time $\tau_{1 / 2}$ of HRP in solution was 17 min under the given conditions. The standard error of the values is $5-12 \%$. ${ }^{c}$ For structural formulas of the coupling reagents see Figure $1 .{ }^{d}$ Not available.

bifunctional aromatic coupling reagents to $\mathrm{NH}_{2}$-glass exhibits a significantly lower thermostability than GOD immobilized by the respective 1,4-bifunctional aromatic reagents.

HRP was immobilized and then explored in the same manner as GOD. As seen in parts $\mathrm{c}$ and d of Figure 2, immobilized HRP is more stable when coupled to the $\mathrm{NH}_{2}$ cellulose support compared to $\mathrm{NH}_{2}$-glass. The best storage stability was obtained for HRP coupled via 1,4-diacetylbenzene or L-ascorbic acid, where it retained $99 \%$ and $97 \%$, respectively, of its initial activity after 30 days of storage. The most stabilizing immobilization of $\mathrm{HRP}$ onto $\mathrm{NH}_{2}$-glass was coupling by means of benzoquinone where the enzyme retained $81 \%$ of the initial activity after 30 days of storage. As seen in Figure 2c, there is no significant effect of the coupling molecule geometry for HRP immobilization via 1,3and the respective 1,4-bifunctional aromatic coupling reagents.

An accepted reason for the stabilization effect of immobilized enzymes is that the active protein conformation is fixed by multipoint bonding formation between the $\mathrm{NH}_{2}$ support and enzyme molecule. ${ }^{22}$ Further, it is described that a smaller number of binding points results in less enzyme stability ${ }^{23} \mathrm{HRP}$ (MW $=44000 \mathrm{~g} / \mathrm{mol}$ ) is a small molecule in comparison to GOD (MW $=185000 \mathrm{~g} / \mathrm{mol}$ ). It could be possible that for this reason a lower number of bonds between the HRP molecule and support surface are sufficient to stabilize the active enzyme conformation by immobilization. This supposition is supported by Garcia et al., ${ }^{24}$ who proved by means of ${ }^{1} \mathrm{H}$ NMR that only approximately 1.7 Lys residues of the protein are accessible when it is immobilized by means of cyanuric chloride (cf. X-ray structure data quantity of Lys residues of HRP protein in Welinder ${ }^{25}$ ). This leads to the conclusion that only a few Lys residues of the HRP protein might react with the 1,3-bifunctional aromatic coupling reagents - similar to cyanuric chloride.

This would diminish the geometry effect because the less favored 1,3-bifunctional aromatic coupling reagents lead to sufficient bond formation between the $\mathrm{NH}_{2}$-functionalized support surface and HRP protein without deforming the active conformation of the enzyme protein.

Regarding the thermostability, coupling of HRP with 1,3or 1,4-diacetylbenzene onto $\mathrm{NH}_{2}$-cellulose film led to the highest stabilization against thermal inactivation at $65{ }^{\circ} \mathrm{C}$. The activity remained $96 \%$ and $92 \%$, respectively, of the initial activity of immobilized HRP after $30 \mathrm{~min}$ of thermal treatment at $65{ }^{\circ} \mathrm{C}$. A high thermostability of the HRP 


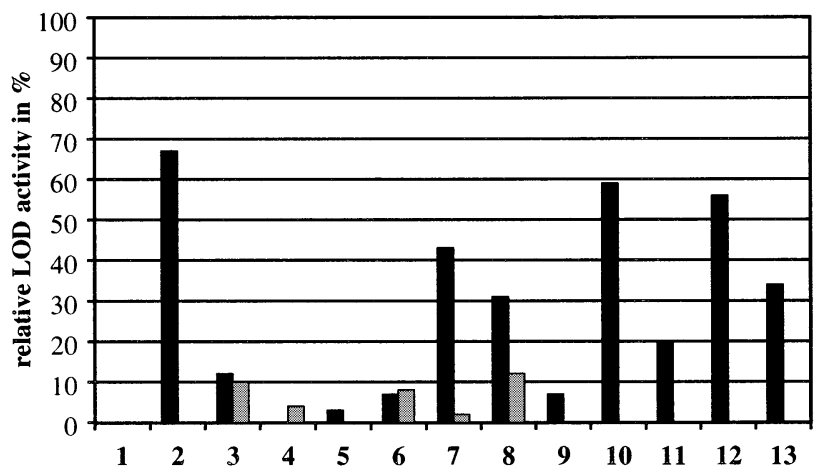

Figure 3. Storage stability of LOD immobilized onto $\mathrm{NH}_{2}$-glass (dark columns) and $\mathrm{NH}_{2}$-cellulose (pale columns) using different coupling reagents (structural formulas see Figure 1).

enzyme was also reached by coupling via amide-bondforming bifunctional reagents, such as L-ascorbic acid (cf. ref 1) and aromatic dicarbonyl and disulfonyl dichlorides, on both $\mathrm{NH}_{2}$-functionalized supports, with the exception of coupling the enzyme by means of the aromatic disulfonyl dichlorides onto $\mathrm{NH}_{2}$-glass (see Figure $2 \mathrm{~d}$ ). Because of this observation, it seems that stabilization of the active enzyme conformation has a bigger influence on the thermostability than the microenvironment.

In the case of LOD, comparable activity values of immobilized enzyme were measured on both $\mathrm{NH}_{2}$-functionalized supports (Table 1), but only the immobilization onto the $\mathrm{NH}_{2}$-glass surface could stabilize the enzyme activity (Figure 3). For example, while LOD coupled by terephthaloyl chloride onto $\mathrm{NH}_{2}$-glass retained $60 \%$ of its initial activity after 30 days storage at $4{ }^{\circ} \mathrm{C}$, the enzyme immobilized onto $\mathrm{NH}_{2}$-cellulose films using the same coupling reagent lost $99 \%$ of its initial activity after only $24 \mathrm{~h}$ at $4{ }^{\circ} \mathrm{C}$. The best storage stability for LOD (preservation of $69 \%$ of its initial activity after 30 days of storage) was achieved by coupling via cyanuric chloride onto $\mathrm{NH}_{2}$-glass and is comparable with literature values. ${ }^{26}$

The enzyme could not be stabilized against thermal degradation. LOD immobilized on both $\mathrm{NH}_{2}$-functionalized supports by means of all the coupling reagents used lost more than $60 \%$ of its initial activity after $30 \mathrm{~min}$ at only $45^{\circ} \mathrm{C}$. As in case of GOD an influence of the molecule geometry of the 1,3- and 1,4-bifunctional aromatic coupling bonds was found for the LOD immobilization. As seen in Figure 3, in most cases, storage stability was found when the enzyme was coupled by the 1,4-bifunctional aromatic reagent compared to coupling by the respective 1,3-bifunctional aromatic reagent. Comparison of the results with GOD, HRP, and LOD leads to the conclusion that the influence of molecule geometry in the 1,3- and 1,4-bifunctional aromatic coupling reagents becomes greater in the order $\mathrm{HRP}<\mathrm{LOD}<\mathrm{GOD}$, i.e., with increasing enzyme size.

Operational stability, a very important factor for the practical use of enzymes in biosensors or as biocatalysts, ${ }^{20}$ was tested for HRP because in the native state this enzyme quickly loses its activity in the presence of its substrate hydrogen peroxide. ${ }^{17}$ To investigate the decrease of HRP activity with operating time, the activity of the enzyme immobilized on $\mathrm{NH}_{2}$-glass and $\mathrm{NH}_{2}$-cellulose films, respectively, by the coupling reagents shown in Figure 1 was continuously measured in a test solution containing $10 \mathrm{mM}$ $\mathrm{H}_{2} \mathrm{O}_{2}$ at $\mathrm{pH} 5.0$ for a time period of $30-40 \mathrm{~min}$. As described in the literature and confirmed by measuring the timedependent activity decrease of HRP dissolved in the abovementioned test solution, the inactivation of HRP in the presence of $\mathrm{H}_{2} \mathrm{O}_{2}$ follows a pseudo-first-order kinetic in a good approximation $(P<0.05) .{ }^{17}$ The HRP activity decreases under the influence of $\mathrm{H}_{2} \mathrm{O}_{2}$ (substrate) in solution. The formation of the inactive HRP intermediate "compound III" (see Dunford et al., e.g., ref 27) is the major reason for this effect. (Compound I and compound II are HRP intermediates containing two or one oxidizing equivalents in the HRP enzymatic cycle.)

The half-life of immobilized HRP was determined by fitting a pseudo-first-order function to the data of the $\mathrm{H}_{2} \mathrm{O}_{2} /$ HRP-enzyme reaction. As seen in Table 2, in all cases, immobilized HRP was stabilized against $\mathrm{H}_{2} \mathrm{O}_{2}$-induced inactivation compared to the native enzyme. Nevertheless, the cellulosic $\mathrm{NH}_{2}$-functionalized support stabilizes the immobilized enzyme to a greater extent than $\mathrm{NH}_{2}$-glass. With respect to the concept of enzyme stabilization by multipoint attachment, ${ }^{22}$ the stability of the immobilizing bonds against hydrolysis must influence the operational stability of HRP, because every cleaved immobilizing bond would lead to a more flexible enzyme conformation resulting in lower stability. The half-lives of HRP immobilized on $\mathrm{NH}_{2}-$ cellulose film (Table 2, column 2) show the presumed effect. While HRP immobilized via amide or sulfonamide bonds (coupling reagents 9-12, see Figure 1) is up to 40 times more stable than the native HRP, immobilization via Schiff's base coupling structures (coupling reagents $\mathbf{3}-\mathbf{6}$, see Figure 1) are less stable against hydrolysis than amide bonds and only stabilize HRP by a factor of $4-8$.

The kinetic properties of the immobilized enzymes are characterized by the apparent Michaelis constant $K_{\mathrm{M} \text {,app }}$, which is a measure of the enzyme-substrate affinity and additionally provides microenvironmental influences for the enzyme-catalyzed substrate conversion. The $K_{\mathrm{M} \text {,app }}$ values of the reaction of oxidoreductase enzymes immobilized onto $\mathrm{NH}_{2}$-glass and $\mathrm{NH}_{2}$-cellulose films were determined as described in the Experimental Section. The immobilized enzyme activities of the investigated samples are given in Table 1 . The $K_{\mathrm{M} \text {,app }}$ values of the immobilized enzymes were in most cases lower than those of the native ones in solution (see Table 3).

While the $K_{\mathrm{M} \text {,app }}$ values of immobilized HRP and LOD do not strongly depend on the coupling reagent but on the nature of the $\mathrm{NH}_{2}$-functionalized support surface (see Table 1), the apparent Michaelis constant of immobilized GOD seems to be influenced drastically by the coupling reagent and the $\mathrm{NH}_{2}$-functionalized support structure $\left(K_{\mathrm{M} \text {,app }}\right.$ values range from 1.4 to $65 \mathrm{mM}$ ). The $K_{\mathrm{M} \text {,app }}$ values found in this study almost cover the wide range of $0.9-66 \mathrm{mM}$ given in the literature. ${ }^{28,29} \mathrm{We}$ found that the $K_{\mathrm{M} \text {,app }}$ values of GOD using the same $\mathrm{NH}_{2}$-functionalized support and coupling reagent decrease with greater immobilized GOD activity. A similar effect was observed for immobilized HRP and LOD, with the difference that the $K_{\mathrm{M} \text {,app }}$ values did not vary by more than $25 \%$. 
Table 3. $K_{\mathrm{M}, \text { app }}$ Values of Oxidoreductase Enzymes GOD, HRP, and LOD Immobilized on $\mathrm{NH}_{2}$-Glass and $\mathrm{NH}_{2}$-Cellulose Films

\begin{tabular}{|c|c|c|c|c|c|c|c|}
\hline \multirow[b]{3}{*}{ no. } & \multirow[b]{3}{*}{ coupling ${ }^{b}$} & \multicolumn{6}{|c|}{$K_{\mathrm{M}}$ values $(\mathrm{mM})$ of the immobilized enzymes ${ }^{a}$} \\
\hline & & \multicolumn{2}{|c|}{ GOD } & \multicolumn{2}{|c|}{ HRP } & \multicolumn{2}{|c|}{ LOD } \\
\hline & & $\mathrm{NH}_{2}$-glass & $\mathrm{NH}_{2}$-cellulose & $\mathrm{NH}_{2}$-glass & $\mathrm{NH}_{2}$-cellulose & $\mathrm{NH}_{2}$-glass & $\mathrm{NH}_{2}$-cellulose \\
\hline 1 & $\mathrm{NaNO}_{2} / \mathrm{HCl}$ & & 2.3 & & 0.25 & & 0.37 \\
\hline 2 & cyanuric chloride & 25 & 17.8 & 0.63 & 0.25 & 0.38 & 0.50 \\
\hline 3 & glutaraldehyde & 18 & 7.1 & 0.52 & 0.30 & 0.40 & 0.35 \\
\hline 4 & isophthalaldehyde & 26 & 15.4 & 0.74 & 0.24 & 0.57 & 0.37 \\
\hline 5 & terephthalaldehyde & 19 & 16.2 & 0.70 & 0.22 & 0.50 & 0.29 \\
\hline 6 & 1,3-diacetylbenzene & 46 & 14.7 & 0.52 & 0.20 & 0.40 & 0.33 \\
\hline 7 & 1,4-diacetylbenzene & 36 & 7.0 & 0.80 & 0.21 & 0.37 & 0.34 \\
\hline 8 & L-ascorbic acid & 11 & 1.4 & 0.67 & 0.23 & 0.35 & 0.28 \\
\hline 9 & isophthaloyl chloride & 65 & 9.2 & 0.86 & 0.32 & 0.51 & 0.35 \\
\hline 10 & terephthaloyl chloride & 32 & 18.8 & 0.35 & 0.19 & 0.45 & 0.40 \\
\hline 11 & 1,3-benzenedisulfonyl chloride & 33 & 5.0 & 0.80 & 0.25 & 0.37 & \\
\hline 12 & 4,4'-biphenyldisulfoyl chloride & 13 & 25.6 & 0.55 & 0.25 & 0.37 & \\
\hline 13 & benzoquinone & 15 & & 0.33 & & 0.50 & \\
\hline
\end{tabular}

${ }^{a}$ The immobilized enzyme activities are given in Table 1 . The $K_{M}$ values of the free enzymes are $37 \mathrm{mM}$ for GOD, $0.70 \mathrm{mM}$ for HRP, and 0.57 for LOD. ${ }^{b}$ For structural formulas of the coupling reagents, see Figure 1.

$\mathrm{NH}_{2}$ cellulose

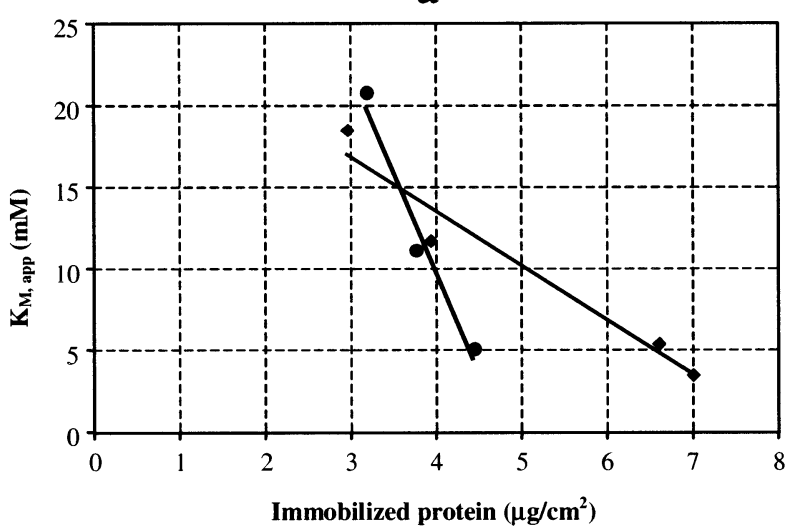

$\mathrm{NH}_{2}$ glass

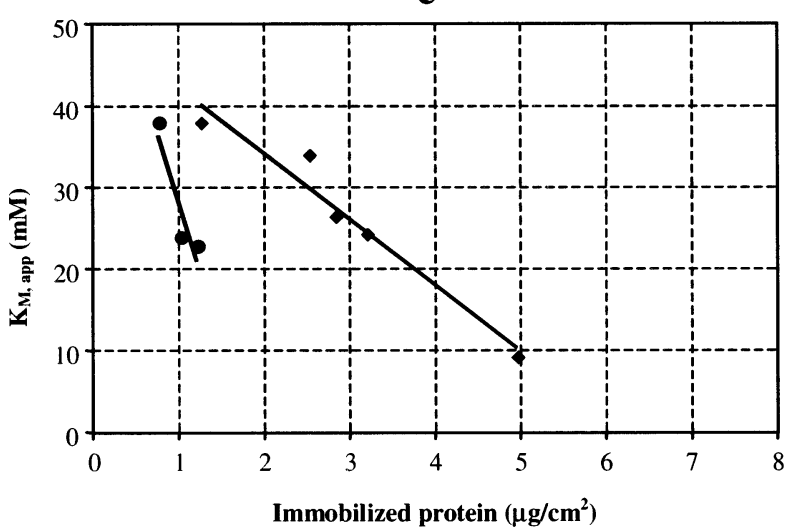

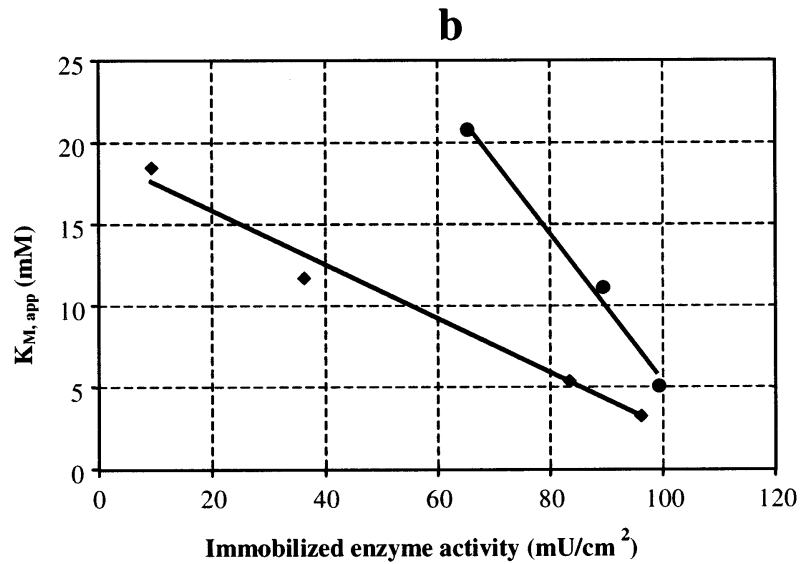

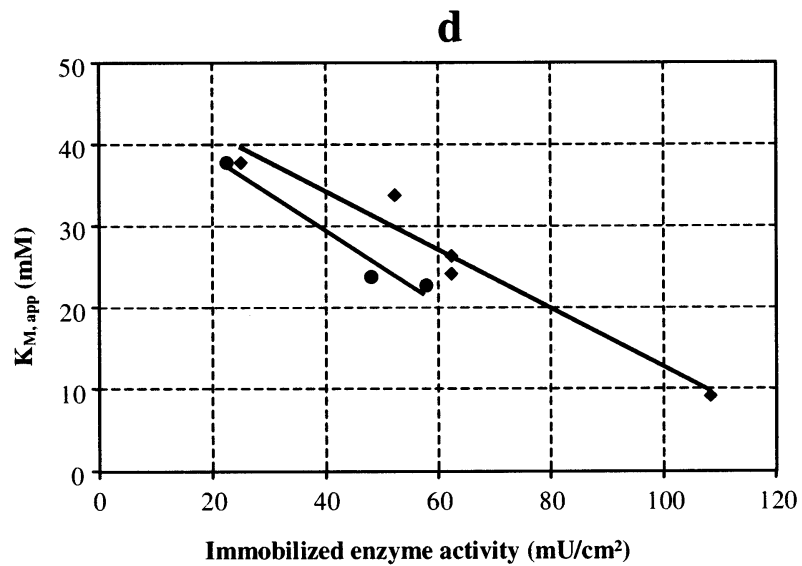

Figure 4. Plot " $K_{M}$ values vs immobilized GOD activities and protein quantities", using the support surfaces $\mathrm{NH}_{2}$-glass and $\mathrm{NH}_{2}$-cellulose films as well as the coupling reagents glutaraldehyde (๑) and L-ascorbic acid $(\bullet)$ : (a) $\mathrm{NH}_{2}$-cellulose films, $K_{\mathrm{M}}$ values vs protein quantities; (b) $\mathrm{NH}_{2}$ cellulose films, $K_{M}$ values vs GOD activities; (c) $\mathrm{NH}_{2}$-glass, $K_{M}$ values vs protein quantities; (d) $\mathrm{NH}_{2}$-glass, $K_{\mathrm{M}}$ values vs GOD activities. Note that lines in the graphs a to $\mathrm{d}$ are drawn by hand to illustrate the general trend of the data. They do not indicate a linear slope.

To explore how the glucose (substrate)-GOD affinity depends on the amount of immobilized enzyme protein as well as on the immobilized enzyme activity, the GOD was coupled by glutaraldehyde and L-ascorbic acid onto both $\mathrm{NH}_{2}$-functionalized supports. By variation of the time of enzyme treatment of the activated support surfaces, GOD could be immobilized with different amounts of enzyme activity and protein quantity per surface. As seen in Figure
4 , the $K_{\mathrm{M} \text {,app }}$ value decreases with increasing immobilized enzyme activity per surface as well as with greater density of coupled enzyme protein.

L-Ascorbic acid, a bifunctional coupling reagent, is capable of fixing high amounts of enzyme protein per $\mathrm{NH}_{2}$-functionalized support surface and exhibits a low specific enzyme activity (up to $23 \%$ for $\mathrm{NH}_{2}$-cellulose films, up to $37 \%$ for $\mathrm{NH}_{2}$-glass). Coupling with glutaraldehyde leads to higher 
specific activities (up to $40 \%$ for $\mathrm{NH}_{2}$-cellulose film, up to $80 \%$ for $\mathrm{NH}_{2}$ glass), but binds less protein. The immobilized GOD enzyme quantity per surface influences the $K_{\mathrm{M} \text {,app }}$ values to a greater extent than the coupling reagent.

The reason for altering the $K_{\mathrm{M} \text {,app }}$ values of immobilized enzymes compared to native ones is not fully understood. ${ }^{30}$ The immobilized enzyme substrate affinity can be affected by real effects, like improving the active conformation of the enzyme molecule, or by apparent effects, such as coupling-induced diffusion phenomena or microenvironmental influences. The effect of increasing substrate affinity of GOD with greater enzyme loading is still under discussion as well. For instance, Gregg et al., who entrapped GOD into a polymer on the surface of an enzyme electrode and measured the enzyme activity as an electrical signal, found decreasing $K_{\mathrm{M} \text {,app }}$ values with greater protein density. ${ }^{31}$ They explained this effect as a hindrance of the electron flow, caused by a diffusion-controlled reaction, which is typical of entrapped enzymes. Klei et al., who found the same effect for GOD immobilized on an ion-exchanger resin from solutions with different concentrations, suggested that a lower distortion of the immobilized enzyme molecules with higher immobilized density would lead to a higher substrate affinity. ${ }^{32}$

In the present study where GOD was in fact immobilized onto the surface of ultrathin support layers, no diffusion phenomena could be observed in the kinetic behavior of the enzyme-functionalized support surfaces, and the concentration of the enzyme in solution was the same for all immobilization procedures. The kinetics of the immobilized enzymes, described in this study, follow the MichaelisMenten mechanism. On principle, in the enzyme reaction there is also the possibility of falsification of $K_{\mathrm{M}}$ values if the enzyme substrate enriches on the $\mathrm{NH}_{2}$-functionalized support surface, where the enzyme is immobilized. In the case of the GOD reaction no indication of glucose enrichment was found on the $\mathrm{NH}_{2}$-cellulose film surface.

The results of the enzyme immobilization, especially in the case of GOD, lead to the conclusion that the $\mathrm{NH}_{2-}$ functionalized support structures exert an optimizing influence on the kinetic and stability, particularly of the immobilized enzyme activity.

Our conception is that the $\mathrm{NH}_{2}$-functionalized support environment influences the "active" GOD-protein conformation probability measure. A working hypothesis is, for example, that $\mathrm{NH}_{2}$ groups present in a positively charged form and less reactive with respect to coupling reagents, have a stabilizing effect on the active conformation of the GOD enzyme.

The degree of deformation of the GOD-protein conformation is affected by the spacer and microenvironmental effects during enzyme immobilization. An "active/inactive" conformational transition ratio (conformational flexibility) is established at the $\mathrm{NH}_{2}$-functionalized support surface, which is fixed to a greater or lesser degree depending on the type of coupling reaction. With increased GOD loading per support surface, the probability measure of the active conformation increases due to the enzyme's own defining microenvironment, which is consequently associated with a decrease in the $K_{\mathrm{M} \text {,app }}$ values of immobilized GOD. Our conception is consistent with the following literature data on GOD immobilization.

For instance, Barmin et al. found a significant decrease in the Michaelis constants of the immobilized GOD in comparison to the native enzyme when the GOD is coupled to a positively charged monolayer of polyethylene imine. ${ }^{33}$ Studies by Li et al. indicated that GOD is strongly adsorbed on positively charged glycolipid monolayers based on akyl2 -amino-2-deoxy- $\beta$-D-glucopyranoside, which is associated with a protein conformation change involving an increase of $\beta$-sheet formation. ${ }^{34}$

In conclusion, $\mathrm{NH}_{2}$-functionalized support surfaces and covalent enzyme immobilization with a large variety of coupling reagents described in this study are a powerful tool for optimizing the properties of oxidoreductase-functionalized support surfaces specifically for each enzyme and support material.

Acknowledgment. The authors are grateful for financial support from the Deutschen Forschungsgemeinschaft granted within the research program: "Cellulose and cellulose derivatives-molecular and supramolecular structural design".

\section{References and Notes}

(1) Tiller, J.; Berlin, P.; Klemm, D. Biotechnol. Appl. Biochem. 1999, $30(2), 155$.

(2) Scouten, W. H. In Methods Enzymology; Mosbach, K. V., Ed.; Academic Press: New York, 1987; Vol. 135, p 30.

(3) Kminkova, M.; Kucera, J. Enzyme Microb. Technol. 1983, 5, 204

(4) Gupta, M. N. Biotechnol. Appl. Biochem. 1991, 14, 1.

(5) Saleemuddin, M. Adv. Biochem. Eng./Biotechnol. 1999, 64, 203.

(6) D'Angiuro, L.; Cremonesi, P. J. Appl. Biochem. 1981, 3, 459.

(7) Reetz, M. T. Adv. Mater. (Weinheim, Ger.) 1997, 9, 943.

(8) Arica, M.; Yakup, H. J. Chem. Technol. Biotechnol. 1993, 58, 287.

(9) Subramanian, A.; Kennel, S. J.; Oden, P. I.; Jacobson, K. B.; Woodward, J. D.; Mitchel J. Enzyme Microb. Technol. 1999, 24, 26.

(10) Ngo, T. T.; Ivy, J.; Lenhoff, H. M. Biotechnol. Lett. 1980, 2, 429.

(11) Emneus, J.; Gorton, L. Anal. Chim. Acta 1993, 276, 303.

(12) Valentova, O.; Marek, M.; Svec, F.; Stamberg, J. Biotechnol. Bioeng. 1981, 23, 2093.

(13) Tiller, J.; Berlin, P.; Klemm, D. Macromol. Chem. Phys. 1999, 200, 1.

(14) Rieseler, R.; Tiller, J.; Berlin, P. Submitted for publication in Adv Mater. Schinkinger, B.; Petzold, R.; Tiller, H.-J.; Grundmeier, G. Appl. Surf. Sci. 2001, 179, 79.

(15) Trinder, P.; Webster, D. Ann. Clin. Biochem. 1984, 21, 430.

(16) Gallati, H. J. Clin. Chem. Clin. Biochem. 1979, 21, 1.

(17) Adediran, S. A.; Lambeir, A. M. Eur. J. Biochem. 1989, 186, 571

(18) Berlin, P.; Klemm, D.; Tiller, J.; Rieseler, R. Macromol. Chem. Phys. 2000, 201, 2070

(19) Tsuchida, T.; Yoda, K. Enzyme Microb. Technol. 1981, 3, 326.

(20) Tiller, J.; Klemm, D.; Berlin, P. Des. Monomers Polym. 2001, 4, 315 .

(21) Buchholz, K.; Klein, J. In Methods Enzymology; Mosbach, K. V., Ed.; Academic Press: New York, 1987; Vol. 135, p 3.

(22) Wang, C.-C.; Hsiue, G.-H. J. Appl. Polym. Sci. 1993, 50, 1141.

(23) Cremonesi, P. Biotechnol. Bioeng. 1983, 25, 735

(24) Garcia, D.; Ortega, F.; Marty, J.-L. Biotechnol. Appl. Biochem. 1998, $27,49$.

(25) Welinder, K. G. FEBS Lett. 1976, 72, 19.

(26) Hall, C. E.; Datta, D.; Hall, E. A. H. Anal. Chim. Acta, 1996, 323, 87.

(27) Dunford, H. B. In Adv. Inorg. Biochem.: Peroxidases; Eichhorn, G. L., Marzilli, L. G., Eds.; Elsevier Biomedical: Amsterdam, North/ Holland, 1982; Vol. 4, p 41.

(28) Vrbova, E.; Marek, M. Anal. Chim. Acta 1990, 239, 263. 
(29) Mikkelsen, S. R.; Lennox, R. B. Anal. Biochem. 1991, 195, 358.

(30) Goldstein, L. In Methods Enzymology; Mosbach, K. V., Ed.; Academic Press: New York, 1976; Vol. 44, p 397.

(31) Gregg, B. A.; Heller, A. J. Phys. Chem. 1991, 95, 5976.

(32) Klei, H. E.; Sundstrom, D. W.; Gargano, R. Biotechnol. Bioeng. 1978, 20, 611.
(33) Barmin, A. V.; Eremenko, A. V.; Sokolovskij, A. A.; Chernov, S. F.; Kurochkin, I. N. Biotechnol. Appl. Biochem. 1993, 18, 369.

(34) Li, J.-R.; Du, Y.-K.; Boullanger, P.; Jiang, L. Thin Solid Films 1999, 352,213

BM020041I 